\title{
An investigation of methicillin-resistant Staphylococcus pseudintermedius (MRSP) in domestic and shelter dogs in Montenegro (RS-Brazil)
}

\author{
Pesquisa de "Staphylococcus pseudintermedius" resistente à meticilina (MRSP) em \\ cães domésticos e de abrigo em Montenegro (RS-Brasil)
}

\author{
MACHADO, Aline Belem ${ }^{1}$; MACHADO, Mirene Fernandes Rosa ${ }^{2}$; PICOLI, Simone \\ Ulrich $^{3 *}$
}

\author{
${ }^{1}$ Universidade Feevale, Instituto de Ciências da Saúde, Programa de Pós-Graduação em Qualidade \\ Ambiental, Novo Hamburgo, Rio Grande do Sul, Brasil. \\ ${ }^{2}$ Mirene Clínica Veterinária, Montenegro, Rio Grande do Sul, Brasil. \\ ${ }^{3}$ Universidade Feevale, Instituto de Ciências da Saúde, Programa de Pós-Graduação em Virologia, Novo \\ Hamburgo, Rio Grande do Sul, Brasil. \\ *Endereço para correspondência: simonepi@feevale.br / simonepi@terra.com.br
}

\section{SUMMARY}

The interaction established between man and their pets has been increasing progressively. The diagnosis of animals carrying methicillin-resistant Staphylococcus pseudintermedius (MRSP) becomes important since positive results for this opportunistic bacteria has been found in humans. The aim of this study was to investigate methicillin-resistant Staphylococcus pseudintermedius (MRSP) in domestic dogs attended in a veterinary clinic and shelter dogs. Anal and nasal swabs from 53 domestic dogs and 46 shelter dogs were collected between the months of August and October of 2015, resulting in 198 samples, which were sent for routine laboratory analysis and subsequently used for this study. Phenotypic tests for bacteria identification and susceptibility to oxacillin were performed for the investigation of MRSP. A total of 23 samples (11.6\%) from 21 dogs were positive for $S$. pseudintermedius, however none of the isolates were MRSP. Nasal and anal swabs had similar positivity and two dogs were carriers of the bacteria in both analyzed sites (anal and nasal). Our results showed a higher positivity for $S$. pseudintermedius in domestic dogs compared to shelter dogs, as well as indicating the importance of collecting more than one colonization site. This is the first study to perform a comparison among different animal creating sites in Brazil.
Keywords: colonization sites, domestic dogs, shelter dogs, MRSP, Staphylococcus pseudintermedius

\section{RESUMO}

O convívio estabelecido entre o homem e seus animais de estimação vem se intensificando progressivamente. O diagnóstico de animais portadores de Staphylococcus pseudintermedius resistente à meticilina (MRSP) se torna importante uma vez que já foram obtidos resultados positivos para esta bactéria oportunista em humanos. O objetivo do estudo foi pesquisar Staphylococcus pseudintermedius resistente à meticilina (MRSP) em cães domésticos atendidos numa clínica veterinária e em cães de abrigo. Entre os meses de Agosto e Outubro de 2015 foram coletados swabs anais e nasais de 53 cães domésticos e de 46 cães de abrigo, resultando em um total de 198 amostras, as quais foram enviadas para análise de rotina laboratorial na Universidade Feevale e, posteriormente, utilizadas para este estudo. Foram realizados testes fenotípicos de identificação da bactéria e de suscetibilidade à oxacilina para a pesquisa de MRSP. Um total de 23 amostras $(11.6 \%)$ oriundas de 21 cães foi positivo para $S$. pseudintermedius, porém nenhum isolado era MRSP. Os swabs nasais e anais tiveram positividade semelhante, sendo dois cães portadores da bactéria em ambos os 
sítios (anal e nasal). Nossos resultados indicaram uma maior positividade para $S$. pseudintermedius em cães domésticos em comparação aos cães de abrigo, além de sinalizar sobre a importância de coletas em mais de um sítio de colonização. Este é o primeiro estudo que realizou uma comparação entre os diferentes locais de criação dos animais no Brasil.

Palavras-chave: sítios de colonização, cães domésticos, cães de abrigo, MRSP, Staphylococcus pseudintermedius

\section{INTRODUCTION}

Staphylococcus pseudintermedius is a gram-positive cocci present in normal microbiota of the skin and mucosa of animals. It can be found in the mouth, groin, perianal region and nostrils, being the latter two the most colonized sites. However, because it is an opportunistic bacteria, it can cause diseases like pyoderma, abscesses, among others (WEESE \& van DUIJKEREN, 2010).

This microorganism may exhibit antibiotic resistance mechanisms. The methicillin resistance (MRSP) is caused by the low affinity that the penicillinbinding protein (PBP) has to beta-lactam antibiotics. This altered PBP (PBP2a) is present in the Staphylococcal Cassette Chromosome mec (SCCmec) (NIEMEYER et al., 1996; WEESE \& van DUIJKEREN, 2010), which causes resistance to beta-lactam antibiotics, making it difficult to treat infections due to limited therapeutic options (PERRETEN et al., 2010; FENG et al., 2012).

The period in which a dog is carrying MRSP is questionable, since $S$. pseudintermedius is an opportunistic bacteria. Therefore, Windahl et al. (2012) tested 31 canines that presented a previous infection whose culture was positive for MRSP. Nineteen dogs (61\%) still had MRSP after 8 months of infection. Thus, even after efficient treatments, there is still the possibility that the dog may be colonized by MRSP without apparent clinical signs.

In addition to animals, humans can also be colonized by $S$. pseudintermedius. In order to analyze the prevalence of human MRSP carriage some studies were performed with dog owners and veterinarians. Only a small positive percentage was obtained however it is not yet determined whether humans are persistently, transiently or contaminated with MRSP (SASAKI et al., 2007; PAUL et al., 2011; LAARHOVEN et al., 2011).

Because $S$. aureus and $S$. pseudintermedius have similar test results there may be an overestimation of MRSA results (methicillin-resistant $S$. aureus) in relation to MRSP. Therefore, correct laboratory identification of these species in clinical materials of human or animal origin is necessary (MALIK et al., 2005; PAUL et al., 2011; van DUIJKEREN et al., 2011), enabling the classification of the bacteria isolates as MRSA or MRSP appropriately.

Given the above, the present study aimed to compare the colonization by MRSP in domestic and shelter dogs in Southern Brazil, being able to improve the diagnosis of human wounds caused by animals providing a better treatment, as wells as a suitable treatment for dogs injured by these bacteria.

\section{MATERIAL AND METHODS}

A total of 99 dogs samples from the Southern region of Brazil were analyzed. An amount of 198 swab samples were collected by the 
veterinarian at the clinic and then they were sent to the University Feevale Laboratory between the months of August and October 2015 for routine laboratory analysis and subsequently used for this research. After all animal owners and legally responsible for the shelters agreed with the study and signed the consent term, these samples were analyzed for our objective. Two swab samples from each animal, one in the nasal region and the other in the anal region, were available for analysis, of which 53 were domestic animals and other 46 dogs were from two shelters in the same city.

It was not included in the study animals that were less than one year old, were treated with antibiotics and/or had used them in the three months prior to collection. Swabs samples were collected at healthy animals during veterinary routine consultation and submitted for the clinical laboratory. So, this study was developed due the samples availability.

To obtain the samples, a sterile swab was moistened with saline solution and then gently introduced into the nostril of the dog; another swab was inserted into the perianal region. Both swabs were maintained in contact with the collecting site for approximately 5 seconds and then placed in Stuart transport medium (BECK et al., 2012). Immediately after collection, all samples were maintained under refrigeration at $4^{\circ} \mathrm{C}$ until their arrival at the Laboratory of Biomedical Sciences at University Feevale, where they were processed within 48 hours after collection and posteriorly used for this study.

Swabs were plated by exhaustion in Columbia agar base with $0.2 \%$ sodium azide and 5\% sheep blood and maintained for 24 hours in the incubator at $37^{\circ} \mathrm{C}$. After this period, morphological characteristics of the presumptive colonies of Staphylococcus pseudintermedius were analyzed (opaque colonies, with double hemolysis, diameter larger than or equal to $1 \mathrm{~mm}$ ) (BEMIS et al., 2009). Suggested colonies of $S$. pseudintermedius were selected, with which the gram stain, catalase and coagulase tests were executed.

Coagulase-positive samples were analyzed by additional identification procedures such as the acid production in D-mannitol agar (weak reaction), presence of pyrrolidonyl arylamidase (PYR), sensitivity to polymyxin B, negative Voges-Proskauer reaction and positive maltose (SASAKI et al., 2007; BEMIS et al., 2009; HUERTA et al., 2011; BANNOEHR \& GUARDABASSI, 2012; QUINN et al., 1994 apud BLUNT et al., 2013).

The diffusion disk method (Kirby Bauer) in Mueller Hinton Agar was performed to identify the methicillin-resistant Staphylococcus pseudintermedius (MRSP). A suspension with the bacteria tested was prepared in sterile saline $(\mathrm{NaCl}$ $0.9 \%$ ) equivalent to a 0.5 McFarland standard. Afterwards, a swab was dampened in the suspension; the inoculum excess was removed by compressing the swab against the tube wall and plated on the Mueller Hinton agar surface. After drying (maximum 15 minutes), the $1 \mu \mathrm{g}$ oxacillin disk was applied, incubating for $18-24 \mathrm{~h}$ at $35^{\circ} \mathrm{C}$ and the diameter of the inhibition zone was measured (van DUIJKEREN et al., 2011; BLUNT et al., 2013). For interpretation purposes, it was considered MRSP when the inhibition zone of $S$. pseudintermedius for oxacillin was less or equal to $17 \mathrm{~mm}$ (BEMIS et al., 2009; SCHISSLER et al., 2009). 


\section{RESULTS AND DISCUSSION}

In the present study, MRSP was not found among the 198 samples of nostrils/anus in domestic and shelter dogs in the Southern region of Brazil. Similarly, a research executed in Rio de Janeiro, Brazil, involving healthy dogs showed that only $1.4 \%(1 / 70)$ of the animals was a methicillin-resistant $S$. pseudintermedius carrier, reinforcing the low frequency of MRSP in the country (QUITOCO et al., 2013). In other research, among 200 shelter dogs in the United States with nasal and perianal samples, only $3 \%$ of them were MRSP carriers (GINGRICH et al., 2011).

Despite the restrictions on the phenotypic methods, due to the lower sensitivity when compared to genotypic tests, these become effective in the MRSP search. This was verified in the Bemis et al. (2006) study, in which they compared, among other methods, the use of $1 \mu \mathrm{g}$ oxacillin disk diffusion and the detection of mecA gene by standard PCR. Through the analyses of the results, a sensitivity and specificity of $97 \%$ and $98 \%$, respectively, was obtained for the oxacillin disk method. Therefore, it is possible to high perform MRSP identification by using phenotypic methods.

It is believed that the higher positivity for $S$. pseudintermedius found among domestic dogs in this study (14 domestic dogs $\mathrm{x} 7$ shelter dogs) may be attributed to exposure to environments with bacteria from other sick animals, which can occur during a routine consultation to a veterinarian physician (LEHNER et al., 2014).

There is little research evaluating the colonization by $S$. pseudintermedius in dogs residing in kennels, as well as studies comparing the colonization by this bacteria among shelter and domestic dogs. Gómez-Sanz and collaborators published two studies addressing these topics: one evaluating the colonization by $S$. pseudintermedius only in shelter dogs (GÓMEZ-SANZ et al., 2013); and another comparing the prevalence of methicillin-resistant $S$. pseudintermedius (MRSP) in domestic and shelter dogs (GÓMEZ-SANZ et al., 2011).

Studies conducted in Spain used a nasal sampling of 196 dogs (98 animals/group), resulting in approximately $12 \%(24 / 196)$ isolates of $S$. pseudintermedius among shelter dogs (GÓMEZ-SANZ et al., 2011, GÓMEZ-SANZ et al., 2013). These findings of $S$. pseudintermedius colonization contradict our results, which of the 99 dogs involved in the study, 21 animals $(21.2 \%)$ were colonized by this microorganism, which was more often observed in $14.1 \%(14 / 99)$ of domestic dogs than in shelter dogs (7/99).

Additionally, it is believed that the Spanish studies could have found a higher frequency of $S$. pseudintermedius if the sampling had been expanded to more than one anatomic site, as evidenced by our study. This study used nostril and anus samples and-found that around $20 \%$ of the animals were colonized by $S$. pseudintermedius (methicillinsensitive/MSSP). Colonization of dogs by $S$. pseudintermedius on both assessed sites (nasal/anal) was practically the same, approximately 6\% (Table 1). Although the bacteria have been commonly found in only one of the sites per animal, it was simultaneously detected in the anus and in the nostril in two domestic dogs $(2 \%)$.

Given the above, it signals the importance of performing collections at more than one site, aiming to increase the detection sensitivity of the bacteria of interest. Paul et al. (2012) research appropriately illustrates the need to evaluate a higher 
number of colonization sites, because $69 \%$ of sampled dogs (82/119) in 4 sites (perianal region, mouth, nostril and groin) were positive for $S$. pseudintermedius.
This number would surely be reduced if the sampling had been restricted to only one anatomic site.

Table 1. Positive swab results for Staphylococcus pseudintermedius colonization in 198 swab samples

\begin{tabular}{lccc}
\hline \multirow{2}{*}{ Samples } & Nostril & Anus & Total \\
\cline { 2 - 4 } & & $\mathrm{n}(\%)$ & \\
\hline Swabs from domestic dogs & $9(4.5)$ & $7(3.5)$ & $16(8.0)$ \\
Swabs from shelter dogs & $3(1.5)$ & $4(2.0)$ & $7(3.5)$ \\
Total n (\%) & $12(6.0)$ & $11(5.5)$ & $23(11.5)$ \\
\hline
\end{tabular}

To date, this is the first study in Brazil that sought to compare the colonization by Staphylococcus pseudintermedius between domestic and shelter dogs. New studies involving both dog groups are needed to evidence more consistent results, seeking to define canine MRSP epidemiology in the different regions of the country.

Although no MRSP isolate was found in this study, the importance of the collection in more than one anatomical site is important because it increases the sensitivity in detecting $S$. pseudintermedius. Discrepancy in the colonization by $S$. pseudintermedius between domestic and shelter dogs was evidenced, indicating the need for additional studies involving both canine groups in different regions of Brazil. The correct identification of the bacteria allows the dog owner to provide the correct treatment for the animal as well as avoiding the increase of resistance to the antibiotics.

\section{REFERENCES}

BANNOEHR, J.; GUARDABASSI, L. Staphylococcus pseudintermedius in the dog: taxonomy, diagnostics, ecology, epidemiology and pathogenicity. Veterinary Dermatology, v.23, p.253266, 2012.

BECK, K.M.; WAISGLASS, S.E.; DICK, H.L.N.; WEESE, S. Prevalence of methicillin-resistant Staphylococcus pseudintermedius (MRSP) from skin and carriage sites of dogs after treatment of their methicillin-resistant or methicillinsensitive staphylococcal pyoderma. Veterinary Dermatology, v.23, p.369$375,2012$.

BEMIS, D.A; JONES, R.D.; HIATT, L.E.; OFORI, E.D.; ROHRBACH, B.W.; FRANK, L.A.; KANIA, S.A.

Comparison of tests to detect oxacillin resistance in Staphylococcus intermedius, Staphylococcus schliferi, and Staphylococcus aureus isolates from canine hosts. Journal of Clinical Microbiology, v.44, p.3374-3376, 2006.

BEMIS, D.A.; JONES, R.D.; FRANK, L.A.; KANIA, S.A. Evaluation of susceptibility test breakpoints used to predict mecA-mediated resistance in Staphylococcus pseudintermedius isolated from dogs. Journal of Veterinary Diagnostic Investigation, v.21, p.53-58, 2009. 
BLUNT, C.A.; VAN VUUREN, M.; PICARD, J. Antimicrobial susceptibility profiles of Staphylococcus intermedius isolates from clinical cases of canine pyoderma in South Africa.

\section{Journal of the South African} Veterinary Association, v.84, p.276, 2013.

FENG, Y.; TIAN, W.; LIN, D.; LUO, Q.; ZHOU, Y.; YANG, T.; DENG, Y.; LIU, Y.H.; LIU, J.H. Prevalence and characterization of methicillin-resistant Staphylococcus pseudintermedius in pets from South China. Veterinary Microbiology, v.160, p.517-524, 2012.

GINGRICH, E.N.; KURT, T.; HYATT, D.R.; LAPPIN, M.R.; RUCH-GALLIE, R. Prevalence of methicillin-resistant staphylococci in Northern Colorado shelter animals. Journal of Veterinary Diagnostic Investigation, v.23, p.947950, 2011.

GÓMEZ-SANZ, E.; TORRES, C.; LOZANO, C.; SÁENZ, Y.;

ZARAZAGA, M.. Detection and characterization of methicillin-resistant Staphylococcus pseudintermedius in healthy dogs in La Rioja, Spain.

Comparative Immunology and Infectious Diseases, v.34, p.447-453, 2011.

GÓMEZ-SANZ, E.; TORRES, C.; BENITO, D.; LOZANO, C.;

ZARAZAGA, M. Animal and human Staphylococcus aureus associated clonal lineages and high rate of Staphylococcus pseudintermedius novel lineage in Spanish kennel dogs: predominance of $S$. aureus ST398. Veterinary Microbiology, V.166, p.580-589, 2013.
HUERTA, B.; MALDONADO, A.; GINEL, P.J.; TARRADAS, C.; GÓMEZGASCÓN, L.; ASTORGA, R.J.;

LUQUE, I. Risk factors associated with the antimicrobial resistance of staphylococci in canine pyoderma. Veterinary Microbiology, v.150, p.302308, 2011.

LAARHOVEN, L.M. de; HEUS, P.; van LUIJN, J.; DUIM, B.; WAGENAAR, J.A.; van DUIJKEREN, E. Longitudinal study on methicillin-resistant Staphylococcus pseudintermedius in households. Plos One, v.6, n.11, e27788, 2013.

LEHNER, G.; LINEK, M.; BOND, R.; LLOYD, D.H.; PRENGER-

BERNINGHOFF, E.; THOM, N.; STRAUBE, I.; VERHEYEN, K.; LOEFFLER, A. Case-control risk factor study of methicillin-resistant Staphylococcus pseudintermedius (MRSP) infection in dogs and cats in Germany. Veterinary Microbiology, v.168, p.154-160, 2014.

MALIK, S.; PENG, H.; BARTON, M.D. Antibiotic resistance in staphylococci associated with cats and dogs. Journal of Applied Microbiology, v.99, p.12831293, 2005.

NIEMEYER, D.M.; PUCCI, M.J.; THANASSI, J.A.; SHARMA, V.K.; ARCHER, G.L. Role of mecA transcription regulation in the phenotypic expression of methicillin resistance in Staphylococcus aureus. Journal of Bacteriology, v.178, p.5464-5471, 1996.

PAUL, N.C.; MOODLEY, A.; GHIBAUDO, G.; GUARDABASSI, L. Carriage of methicillin-resistant Staphylococcus pseudintermedius in small animal veterinarians: indirect evidence of zoonotic transmission.

Zoonoses and Public Health, v.58, p.533-539, 2011. 
PAUL, N.C.; BÄRGMAN, S.C.; MOODLEY, A.; NIELSEN, S.S.; GUARDABASSI, L. Staphylococcus pseudintermedius colonization patterns and strain diversity in healthy dogs: a cross-sectional and longitudinal study. Veterinary Microbiology, v.160, p.420427, 2012.

PERRETEN, V.; KADLEC, K.; SCHWARZ, S.; ANDERSSON, U.G.; FINN, M.; GREKO, C.; MOODLEY, A.; KANIA, S.A.; FRANK, L.A.; BEMIS, D.A.; FRANCO, A.; IURESCIA, M.; BATTISTI, A.; DUIM, B.;

WAGENNAR, J.A.; VAN DUIJKEREN, E.; WEESE, J.S.; FITZGERALD, J.R.; ROSSANO, A.; GUARDABASSI, L. Clonal spread of methicillin-resistant Staphylococcus pseudintermedius in Europe and North America: an international multicentre study. Journal of Antimicrobial Chemotherapy, v.65, p.1145-1154, 2010.

QUITOCO, I.M.Z.; RAMUNDO, M.S.; SILVA-CARVALHO, M.C.; SOUZA, R.R.; BELTRAME, C.O.; DE OLIVEIRA, T.F.; ARAÚJO, R.; DEL PELOSO, P.F.; COELHO, L.R.; FIGUEIREDO, A.M.S. First report in South America of companion animal colonization by the USA1100 clone of community-acquired methicillin-resistant Staphylococcus aureus (ST30) and by the European clone of methicillin-resistant Staphylococcus pseudintermedius (ST71). BMC Research Notes, v.6, p.336, 2013.

SASAKI, T.; KIKUCHI, K.; TANAKA, Y.; TAKAHASHI, N.; KAMATA, S.; HIRAMATSU, K. Reclassification of phenotypically identified Staphylococcus intermedius strains. Journal of Clinical Microbiology, v.45, p.2770-2778, 2007.
SCHISSLER, J.R.; HILLIER, A.; DANIELS, J.B.; COLE, L.K.; GEBREYES, W.A. Evaluation of Clinical Laboratory Standards Institute interpretive criteria for methicillinresistant Staphylococcus pseudintermedius isolated from dogs. Journal of Veterinary Diagnostic Investigation, v.21, p.684-688, 2009.

VAN DUIJKEREN, E.; CATRY, B.; GREKO, C.; MORENO, M.A.; POMBA, M.C.; PYÖRÄLÄ, S.; RUŽAUSKAS, M.; SANDERS, P.; THRELFALL, E.J.; TORREN-EDO, J.; TÖRNEKE, K.

Review on methicillin-resistant Staphylococcus pseudintermedius. Journal of Antimicrobial Chemotherapy, v.66, p.2705-2714, 2011.

WEESE, J.S.; VAN DUIJKEREN, E. Methicillin-resistant Staphylococcus aureus and Staphylococcus pseudintermedius in veterinary medicine. Veterinary Microbiology, v.140, p.418429, 2010.

Data de recebimento: 02/08/2017

Data de aprovação: 22/11/2017 